\title{
Blake Nevius
}

\section{COOPER'S LANDSCAPES \\ An Essay on the Picturesque Vision}

\&

University of California Press

Berkeley, Los Angeles, London 


\title{
ABOUT \\ QUANTUM \\ BOOKS
}

\author{
QUANTUM, THE UNIT OF \\ EMITTED ENERGY. A QUANTUM \\ BOOK IS A SHORT STUDY \\ DISTINCTIVE FOR THE AUTHOR'S \\ ABILITY TO OFFER A RICHNESS OF \\ DETAIL AND INSIGHT WITHIN \\ ABOUT ONE HUNDRED PAGES \\ OF PRINT. SHORT ENOUGH TO BE \\ READ IN AN EVENING AND \\ SIGNIFICANT ENOUGH \\ TO BE A BOOK.
}




\section{COOPER'S LANDSCAPES}


University of California Press Berkeley and Los Angeles, California

University of California Press, Ltd.

London, England

Copyright (C 1976, by

The Regents of the University of California

ISBN 0-520-02751-5

Library of Congress Catalog Card Number: 74-77730

Printed in the United States of America 